\title{
Coordination mechanisms in the store opening process
}

\author{
Erik Sandberg \\ Linköping University Post Print
}

N.B.: When citing this work, cite the original article.

Original Publication:

Erik Sandberg, Coordination mechanisms in the store opening process, 2014, International Journal of Retail \& Distribution Management, (42), 6, 482-499.

http://dx.doi.org/10.1108/IJRDM-01-2013-0024

Copyright: Emerald

http://www.emeraldinsight.com/

Postprint available at: Linköping University Electronic Press

http://urn.kb.se/resolve?urn=urn:nbn:se:liu:diva-109475 


\title{
Coordination mechanisms in the store opening process
}

\begin{abstract}
Purpose - For many retailers organic growth through the opening of new stores is a crucial cornerstone of the business model. The purpose of this study is to explore the store opening process conducted by retail companies. The research questions cover (1) the role and organisation of the establishment function in charge of the process, (2) the activities and functions involved in the process, and (3) the coordination mechanisms applied during the process.
\end{abstract}

Design/methodology/approach - This research considers the store opening process as a company-wide project, managed by an establishment function, in which internal functions as well as external suppliers need to be coordinated. A multiple case study of eight retail companies is presented, focusing on the organisation of the establishment function, a mapping of the store opening process, and the application of coordination mechanisms.

Findings - The role and organisation of the establishment function is described and the store opening process is summarised into eleven main activities to be conducted by either the establishment function or other involved functions. During the store opening process six different coordination mechanisms are utilised, including mutual adjustments and direct supervision, as well as different types of standardisation.

Originality/value - This research seeks to improve our understanding for the store opening process and how it can be managed and controlled in an effective manner.

Keywords Store opening process, establishment, organisation, coordination mechanisms

Paper type Research paper

\section{Introduction}

The store opening process plays a major role in many retail companies. Store openings in new markets as well as the penetration of existing ones are accomplished through a cross-functional project managed by an establishment function at the company. The project follows a standardised, often well-defined process ranging from market planning, via the finding of suitable store location, contract writing and renovation, to full-scale, on-going business (Rosenblum, 2005). The output from the process, i.e. the store, is in itself also a product of a well-defined store concept in terms of size, equipment, layout, etc. In strategic management research companies with standardised opening process and store concept are considered to have a replication strategy, defined as "the creation and operation of a large number of similar outlets that deliver a product 
or a service" (Winter and Szulanski, 2001, p. 730). The replication strategy has become a popular growth model, and has been identified in more than 60 industries (Winter and Szulanski, 2001).

The store opening process represents a great coordination challenge. Internal functions must be involved and linked together, as well as external suppliers. Chen et al. (2009) comment and summarise the coordination challenge in the store opening process in the following lines:

"In order to optimize success, a massive coordination of efforts and resources is needed to bring all areas on board, such as marketing, logistics, financial, human resources, etc. Diverse areas ranging from store design, installation of fixtures and shelving, training of staff, technology installation, developing distribution delivery schedules, and designing promotional announcements must all be coordinated to support the targeted opening date. The coordination must encompass functional areas and processes across the organization." (Chen et al., 2009, p. 15)

The purpose of this article is to explore the store opening process conducted by retail companies. Related to Winter and Szulanski's definition of replication strategy, relatively little attention has been given to the creation of the store. This research area has so far been occupied mainly with research on international expansion of retailers covering topics such as effects of international expansion (Etgar and Rachman-Moore, 2008), choice of entry modes (Park and Sternquist, 2008) and challenges (Pioch et al., 2009). In addition, methods and strategies around the important issue of site location has been developed (e.g. Alexander et al., 2008; Craig et al., 1984; Reynolds and Wood, 2010; Shanmugam, 2013). However, little research has been made on the entire store opening process.

This research considers the store opening process as a company-wide project management process (Padar et al., 2011; Ward, 1999) controlled by an establishment function. This function is normally organised into an organisational unit completely or partly dedicated to the establishment of new stores of the retail chain. Research questions addressing who, what and how concerning the store opening process are posed. The article first clarifies the role and organisation of the establishment function in the retail company that is in charge of the process (who?). Secondly, the process in itself is mapped and described in sequential steps (what?). Third, by exploring different coordination mechanisms applied, this article seeks to improve our understanding for how the store opening process can be managed and controlled in an effective manner (how?). To conclude, the article has three research questions:

1. Who: What is the role and organisation of the establishment function in a retail company?

2. What: How can a store opening process be described in terms of activities, organisation and the involvement of multiple company functions?

3. How: How are involved company functions coordinated during the store opening process?

Coordination mechanisms play a vital role in what is labelled "coordination theory". In their seminal paper, Malone and Crowston (1994) define coordination to be "managing 
dependencies between activities" (p. 90). Given this definition, the existence of interdependencies among stakeholders and involved activities become necessary prerequisites for coordination.

The research is based on a multiple case study of eight retail chains operating in Sweden, each with a standardised establishment process based on a replication philosophy. Interviews with managers responsible for new store establishments and other involved functions have been conducted, and internal, classified documents relating to the store opening process have been studied.

The remainder of this article starts with a short introduction to the store opening process and a framework of coordination mechanisms. Thereafter the methodology is addressed, which is followed by the findings related to each of the three research questions posed. Finally, conclusions are drawn and future research areas are introduced.

\section{Frame of reference}

\section{The store opening as a project management process}

The opening of a new store is in this research considered to be a project management process, typically defined as "a temporary endeavour undertaken to create a unique product, service, or result" (Project Management Institute, 2008). It can be described as a systematic method for executing projects with five general phases: Conceptual, Analysis, Definition, Execution, and Evaluation (Uppal, 2008). A typical feature of the store opening process, as for many other project management processes, is the many stakeholders involved in the process, which complicates and intensifies the coordination challenges (Ward, 1999).

There is little academic research investigating the store opening process. One exception is Rosenblum (2005), who introduces a life cycle approach to stores that encompasses the opening, remodelling and closing phases of a store's life. Focusing on the store opening process, this starts according to Rosenblum with a market planning phase in which the demographic and psychographic characteristics of the market, as well as the competition, are evaluated. Thereafter a suitable property for the store is selected based on e.g. demographics within a radius around the property and costs associated with the specific site. The next phase concerns construction and installation of equipment. Finally, after the store opening, the lease and facilities management phase covers the actual operation of the store. In literature, there are also a couple of examples of the store opening process at specific companies such as H\&M. Bengtsson (2008) describes H\&M's opening process with the very general phases of Contract (of a site location), Build shop, Shop opening, Support, and Support leaves. More detailed mappings of the store opening process is however lacking in existing literature.

\section{On coordination mechanisms in project management processes}

Appropriate coordination mechanisms are essential for a successful project management process such as a store opening process. Although applied in many research fields, most attention to coordination mechanisms has been given by 
organisation researchers (Malone and Crowston, 1994). Existing research often considers coordination mechanisms to be specific tools, designed to address and eliminate uncertainties (Malone and Crowston, 1994; Ward and Chapman, 2008). Overall, an important starting point to understand risks or uncertainties involved, are the basic questions of (Ward and Chapman, 2008):

1. Who: who are the parties involved?

2. Why: what do the parties want to achieve?

3. What: what is it the parties are interested in?

4. Which way: what needs to be done?

5. Wherewithal: what resources and involved/required?

6. When: what are the pertinent timescales?

Related to the first point above, Ward (1999) develops the reasons for uncertainty when multiple stakeholders are involved in the project (which is typically the case in a store opening process). For instance, involvement of multiple stakeholders introduces uncertainty associated with different objectives and expectations of the stakeholders, specification of responsibilities, communication lines, capabilities of different stakeholders, formal contract conditions, etc. (Ward, 1999). Appropriate coordination mechanisms are needed in order to remove these sources of uncertainty.

In organisation and project management literature there is a growing body of literature that suggests different types of coordination mechanisms (e.g. Fugate et al., 2006; Shen and Chang, 2011). For example, based on research in a construction engineering environment, Shen and Chang (2011) identify the following eight coordination methods (mechanisms): meetings, informal discussions, site visits, written correspondence, plans, schedules, reports, and contract documents. At a very general level, focusing on the involvement of people in the organisation, Van de Ven et al. (1976) introduce the coordination mechanisms of impersonal, personal and group mode. Impersonal coordination refers to "the use of pre-established plans, schedules, forecasts, formalised rules, policies and procedures, and standardised information and communication systems" (Van De Ven et al., 1976, p. 323), where little or no personal contact is required. Personal coordination is adopted when individuals, in communication with other people, coordinate activities. This communication can be both vertical (top-down, bottom-up in a company) as well as horizontal (e.g. between company functions). Finally, the group mode means coordination in scheduled as well as unscheduled meetings. In a store opening process, which is a complex process with many stakeholders involved, it is necessary to apply a combination of Van de Ven et al.'s (1976) coordination types. A variety of coordination methods could be applied, of which Shen \& Chang's (2011) examples from the construction engineering industry may be possible.

A more general classification of coordination mechanisms, independent from type of company, industry, etc, but still more detailed in comparison to Van De Ven et al.'s (1976) classification, is based on Mintzberg's six coordination mechanisms (e.g. Glouberman and Mintzberg, 2001). In this framework, which will be applied in this research, it is argued that organisations exploit a mixture of six basic coordination mechanisms: 
1. Mutual adjustment means that two or more people adapt to each other during the process. As indicated by Chen et al. (2009) a store opening process contains cross-functional involvement and decision-making based on knowledge from a wide range of different fields. This often calls for mutual adjustment.

2. Direct supervision is when someone else is performing the coordination. Typically this can be a supervisor or manager in a hierarchy of authority that issues directives for how work should be done. In the store opening process the establishment manager may have this role.

3. Standardisation of work, which means that the working procedures in themselves are specified. Typical for retail companies with a replication strategy, routines and checklists used in the store opening process refer to this type of coordination mechanism.

4. Standardisation of outputs, which means that the output from the activities conducted is standardised in order to match with other activities, i.e. the interfaces between activities are standardised.

5. Standardisation of skills and knowledge, which gives the opportunity for people to know what to expect from each other in terms of work, thus enabling greater synchronity.

6. Standardisations of norms, meaning that common values and beliefs shall facilitate that people are working towards the same goals and expectations.

The utilisation of suitable coordination mechanisms, internally among company functions as well as externally with suppliers and customers, is expected to increase efficiency and effectiveness in the company's operations. In literature a long list of different benefits are discussed, such as risk reduction, cost improvements, inventory reduction, and higher profits (Fugate et al., 2006). At an overall level, proper coordination maximises value creation (Sandberg and Bildsten, 2010)

\section{Methodology}

The main focus for this research has been to cover the company-wide store opening process through an explorative, multiple case study as discussed by Yin (2003). The research at hand contains three research questions relevant to a number of retailrelated research disciplines, such as strategic management, marketing and logistics. The establishment function, activities in the store opening process, and applied coordination mechanisms have been investigated and empirically discovered (Meredith, 1989) in an explorative manner (Yin, 2003).

After an initial screening of the literature on store opening processes, which is limited, a first draft of the paper was developed incorporating the research questions and theory on coordination mechanisms. An interview guide with open-ended questions was also developed; the use of open-ended questions through a semi-structured interview guide was a conscious choice, in order to focus on informants' own description of the opening process. The author has given no specific emphasis on coordination during the interviews, although this has been a recurrent topic during almost all interviews. 
The case study was conducted during autumn 2012. In total 12 people at 8 retail companies with self-service outlets operating on the Swedish market (and sometimes in other markets as well) were interviewed. For a brief overview of the companies, see Appendix 1. Two interviews were conducted by telephone, and the others face-to-face. The case companies have been selected to warrant coverage of a broad range of sectors, in order to facilitate external validity. Additionally, the case companies are of a similar size and each company claims to have a standardised store concept as well as a standardised store opening process that is managed by one establishment function. Although interesting for future studies, the potential complexities of access and more highly differentiated establishment functions mean that the opening processes of large multinational retail companies is beyond the scope of this research. The focus on the Swedish market may also limit the possibilities for generalisation of the results to this study, although the Swedish market as well as company structures is similar to other ones within the European Union. Several of the companies are operating also in other countries and the informants have not indicated any peculiarities or circumstances specific for store opening processes in Sweden.

As a major informant the manager in charge of the establishment function at each company has been interviewed. In order to secure a full understanding of the process and to provide a point of triangulation (Yin, 2009), other senior managers apart from the managers of the establishment functions were also interviewed see Table 1.

\section{Table 1: Informants in the study}

\begin{tabular}{|c|l|}
\hline Company & Title(s) of informant(s) \\
\hline A & Establishment Director, Logistics Manager \\
\hline B & Establishment Manager, Supply Chain Manager \\
\hline C & Logistics and IT Manager \\
\hline D & Establishment Manager, Logistics Inbound Manager \\
\hline E & Establishment Manager, Manager Central Warehouse \\
\hline F & Head of Central Services \\
\hline G & Establishment Manager \\
\hline H & Owner \\
\hline
\end{tabular}

Table 1: Informants in the study 
To improve validity as well as reliability, the conducted interviews have been complemented with other sources of information (Yin, 2003; Gibbert et al., 2008). For the purpose of this research classified checklists for the project leaders, and presentations used for internal education purpose made by the establishment functions, have been a very valuable source for information. Another strategy for increasing the validity has been to let all interviewees review a written summary of their establishment function and specific store opening process as perceived by the author. This has made it possible for the informants to correct the author's interpretation. Additionally, a draft of the full paper has also been provided to all informants as a means of verifying the empirical findings.

Stuart et al. (2002) claim the process of interpreting qualitative data in the analysis phase to be "a challenge of making sense from chaos" (p. 427). To decrease complexity in the analysis process the author conducted the analysis in two steps; one within-case analysis which was followed by a cross-case analysis (Yin, 2003). The within-case analysis, which main output was findings on each single case company's store opening process in a table-format, served to develop an in-depth understanding of each case company separately. Thereafter, when each case company had been analysed, the case companies were compared to each other in the cross-case analysis. In particular, similarities in the case companies' establishment functions, store opening processes and use of coordination mechanisms were identified and summarised.

\section{Findings}

\section{The establishment function}

The establishment function is considered an important business function among the case companies, and each company except one (company $\mathrm{H}$ ) has an organisational department completely or partly dedicated to the establishment of new stores (for information about each case company, see Appendix 2). Typically, other tasks handled by the establishment function are the maintenance of existing properties, management of rental agreements, etc. Its organisational belonging in terms of reporting structures and hierarchies differs however among the companies. Overall the establishment function reports either to the CEO (Chief Executive Officer) or CFO (Chief Financial Officer). In addition to the reporting structure, its organisational relationship to other company functions also varies between the case companies. In particular the sales and/or marketing function(s) is closely related to the establishment function. This is natural due to the involvement and important role of regional sales managers in the store opening process. Many activities conducted during the store opening process are jointly executed by the establishment and sales departments, e.g. the identification of a possible site location, collection of relevant information about the location (as an input for a formal investment decision), marketing campaigns and advertising during the opening, store layout issues, etc. In some of the companies the establishment function is also closely related to the logistics function, either by having the same manager, or by close collaboration in terms of cost calculations (part of information gathering before a formal investment decision), and issues concerning the future flow of goods such as 
planning at the CW (Central Warehouse). In conclusion, the establishment function appears to be an organisationally independent unit, reporting directly to CEO or CFO, but at the same time, in terms of activities, closely intertwined with the functions of sales and marketing as well as logistics.

During the store opening process, the formal tasks for the establishment function are in the beginning of the process very similar among the cases. The main task is to find suitable site locations and deliver decision material to top management (e.g. a establishment council or similar) who decides on the investment). Later on in the store opening process, the establishment function continues to follow the progress in the form of a supervising role. The normal case is that the assigned project leader for the opening process is employed by the establishment function. In a number of companies the establishment function also takes active part in the actual execution of the store opening process such as installations, receipt of goods and stacking, etc. A common organisation in the later stages of the store opening process is that members of the establishment function (project leader and merchandisers) work together with the newly employed store personnel to finalise and prepare the store for opening.

\section{The store opening process}

As for many project management processes, although the general activities performed during a store opening process are the same or very similar, the processes differ considerably at a detailed level in terms of activities, people responsible for and executing the activities etc. (Crowston, 1997). Figure 1 below illustrates a framework of the opening process in 11 major activities that occur at least to some extent in all case companies. 


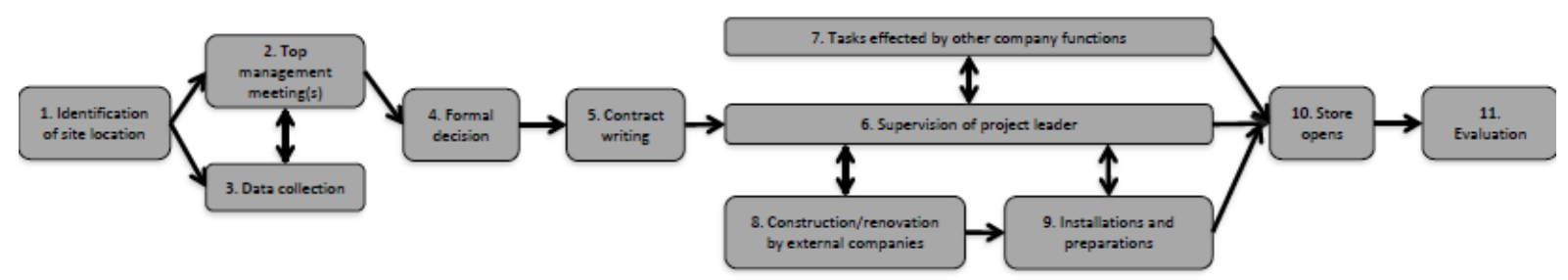

Figure 1: The store opening process

1. Identification of site location. Based on an overall establishment- and market-strategy the case companies continuously scan the market for new site locations. Due to surplus site locations in Sweden at the moment, the most common way to get in touch with a specific site location is when an agent or landlord contacts the establishment manager or someone else in the company (often regional sales manager) to promote a certain location. Establishment managers do also, based on the establishment strategy, proactively search for new locations in certain areas or regions that are of interest for the company.

2. Data collection. After an initial proposal has been made on a specific site location, decision data material is gathered. The decision data material, upon which the formal decision of establishment is taken, mainly consists of

1. A market analysis including demographic figures, the surroundings, and competitors,

2. Profit calculation, including costs and expected turnover, and

3. Initial drawings of the store.

Several company functions are involved during the data collection, in particular regional sales managers. In some companies the logistics function also plays a vital role for proper cost calculations. The establishment manager is often responsible for the data 
collection (although this is sometimes delegated to the intended project leader, coordinating the involved functions). The establishment manager is also the main negotiation partner towards the landlord, agent or similar. If any building licences are needed this is also handled by the establishment function.

3. Top management meetings. Most of the companies have some kind of formal top management meeting(s) typically labelled "establishment council", or "investment council", where the plans for a future store opening is discussed. The composition of the participants of the meetings varies between the companies, as does the role of the establishment manager. In some companies the establishment manager is member of the group, whereas in other companies the establishment manager is represented by his/her manager (e.g. executive vice president, CEO, or similar).

4. Formal decision. The top management team has responsibility for the formal decision, which is made after they have considered the data decision material. They may also have an advisory role.

5. Contract writing. After the formal decision is taken the negotiation with landlord is finalised (if not done before). The contract is written, including agreements about what should be constructed/renovated by the landlord and other future claims on the landlord.

6. Supervision of project leader. After the contract is signed the establishment function formally gets the responsibility for management of the store opening process. A project leader is assigned by the establishment manager and a start-up meeting is normally held. Other resources at the establishment function such as merchandisers and architects are informed. The supervision of the opening process made by the project leader follows a standardised procedure, often included in a detailed checklist with different tasks, and at what stage in time they should be executed.

7. Tasks effected by other company functions. Apart from the establishment function, a number of other company functions get involved during the opening process mainly due to their knowledge and expertise. These functions are allocated subtasks to be executed along the process. In some companies other functions also have their own standardised checklists of their duties during an opening process, supervised by the project leader. One example related to the future flow of goods is the planning and execution of campaigns in connection to the store opening. In this phase of work, marketing management or similar, as well as purchasing departments get involved.

8. Construction/renovation by external companies. All companies outsource the actual construction work during the opening process, and many of the companies also outsource all renovation activities. Supervised by the project leader, companies often favour using the same external contractors on multiple occasions, in particular in the cases where the store concept is well developed. The construction ends with a formal inspection.

9. Installations and preparations. In contrast to the construction/renovation phase, the installation and preparation of the store is often completed by the establishment function and other internal resources, although external suppliers of IT-system and 
equipment also take part in the process. This phase is normally led by the project leader and merchandisers, and occurs in the 5-6 weeks before the opening day. Merchandisers conduct a number of tasks related to the final preparation of the store such as the ordering of a first large batch of goods to be sold, i.e. a starting kit, and stacking of the goods in the store. The store manager and new personnel are also trained and involved during this phase.

10. Store opens. Store openings are often planned to coincide with the month end (when salaries are paid in Sweden).

11. Evaluation. Some time after the opening a new round of inspections of installations, the construction, etc. normally takes place. The sales performance of the store is also incorporated in the regular follow-up reports in the company. However, very seldom a more formal evaluation of the store opening process in itself is conducted. Only one company (company H) states that there is a formal evaluation of the process and that checklists or similar are corrected in accordance with this evaluation.

\section{Coordination mechanisms applied during the store opening process}

A major task for the establishment function is to coordinate other company functions during the store opening process. For this a number of different coordination mechanisms are applied. The coordination is discussed and exemplified in this section, using Mintzberg's six coordination mechanisms of mutual adjustments, direct supervision, and standardisation of work, outputs, skills and knowledge, and norms.

Mutual adjustment. Although each case company claims a high degree of standardisation in their store opening process, a specific process always contains modifications for instance in terms of timing, people and functions involved, and actual store layout. As pointed out by one establishment manager, beyond the standardised procedures, meetings, and checklists, there is always a need to consider and adapt to the actual situation. Coordination through mutual adjustments is probably the most important mechanism applied, and occurs mainly during meetings (formal as well as informal). One example is advertising and product campaigns conducted in connection to the opening. The campaigns are to be initiated by marketing or sales function, and coordinated with purchasing as well as logistics a long time before opening in order to secure product availability. With the project leader as a coordinating force, keeping track of the progress and time schedule of the opening process, representatives from the different functions meet to work out the details around the campaign. Another example is the adjustments between the actual deliveries of IT systems, equipment, and goods during the installation phase close to the store opening date. Several informants witness some chaotic weeks where different suppliers are not always synchronised in time and deliveries. Ad hoc solutions to solve a problematic situation are common. With proper mutual adjustment this chaos however very seldom results in a delayed opening of the store.

Direct supervision. As indicated in the description above an important activity during the store opening process is supervision by the project leader. Although not a more senior hierarchical rank, the project leader, and his/her manager, the establishment manager, are assigned by the top management team to be in charge of the store opening. 
Considered as a highly strategic and prioritised area in the company, and with support from a routinized, accepted process, the establishment manager is able to exert pressure and demand actions to be taken by the other involved functions. Examples from the cases includes the ordering of delivery plans to be worked out by the logistics function, ordering and management of IT system installations, and management and instructions given to the newly employed personnel.

Standardisation of work. Together with mutual adjustments, the standardisation of work in terms of checklists is probably the most commonly used coordination mechanism in the store opening process. Apart from the project leader's own checklist, there are also other checklists available for other involved functions during the process, e.g. the logistics department (to make necessary delivery plans), and the IT supplier (to incorporate the new store in the system). Standardisation of work is also accomplished through the means of communication applied during the process. In time (at a certain point during the process) planned meetings is the most commonly used way, but another possibility conducted by one of the companies is a joint IT platform where information about the progress is shared.

Considering the companies' standardisation of work, many "smart", simple solutions have been developed and refined during the years of store openings. For instance, one of the case companies has introduced a standardised method for the efficient replenishment of goods from the initial start-up kit. First, in order to avoid uncertain and varying order quantities, the initial product order is always for two packages of each product, which are delivered and stacked out in the store. Thereafter, when it is possible to visually see the space left for more products, a second round of goods are ordered from the CW.

Standardisation of output. The result of a store opening process is a new store. The more standardised the output of the process is, i.e. the store, the better possibilities for coordination there are. Companies with a highly standardised store layout including planograms, makes it easier to order a correct amount of products with the first, initial order batch. Division of work between functions also becomes smoother when the time to install, replenish, build etc. is known and therefore better planned. Another example of standardised output, which is emphasised from a logistics perspective, is the advantage of having the same product range in all stores to be opened. By having the same product range many misunderstandings between involved functions can be avoided. An important output factor is also the time schedule for the process. As soon as the opening date is decided, this facilitates the planning and coordination for the different activities in the process.

Standardisation of skills and knowledge. In most of the case companies the project leader, together with the establishment manager, are responsible for keeping track and follow up skills and knowledge in the company. Supervised by the establishment function, other functions are asked for input based on their expertise during the process, for example the logistics department delivers the logistics cost calculations that forms the basis for the data decision material. Several informants in the case companies conclude the importance of conducting store openings on a regular basis as a means of upholding the routines and remembering what to do during the different stages of the process. This also includes knowing and trusting what other involved functions do in the process. 
Standardisation of norms. Meetings are of major importance to stakeholders throughout the store opening process. Top management meetings can help generate commitment to the store opening process, and general meetings inform stakeholders about the company's future organic growth. To align different functions, beliefs and values about the company's establishment policy, the establishment manager plays a vital role as an information and internal champion. The case companies also witness the necessity to get support from CEO and board of directors.

\section{Conclusions}

In order to better understand the strategically important, company-wide store opening process conducted by retailers, this research explores (1) the role and organisation of the establishment function, (2) the activities and functions involved in the store opening process, and (3) the coordination mechanisms applied during the opening process. The findings indicate a relatively complex organisational situation for the establishment function, often designed as an independent, stand-alone function that is expected to balance and coordinate other company functions. This complements research on the location decision process, here understood as being a part of the wider store opening process. A study of Reynolds and Woods (2010) confirms the involvement of other company functions, in particular property, operations and marketing departments, but also sales and purchasing in the location decision. For the execution of a store opening process, the establishment function, right or wrong, is heavily dependent on other company functions. The process is in this research summarised into a framework including 11 main activities. The single largest challenge during a store opening process is proper communication between the different company functions involved in the process (Rosenblum, 2005; Thomas et al., 1998). To enhance proper communication, and align different company functions with each other along the process, a combination of Mintzberg's six coordination mechanisms are applied.

Despite its strategic relevance for having a replication strategy, there is surprisingly little academic research examining the store opening process and this research therefore contributes to research by providing a summarising framework of the major activities involved in the store opening process. This research expands the existing research on methods and strategy around site location, which is a relatively well established research field, to also include the later stages of the process, e.g. construction and installations. By incorporating a larger part of the process, and adding a discussion on coordination mechanisms, important insights of how the process is designed, and how it is managed, is enhanced. Being a cross-functional process, the improved understanding for the store opening process could be of value for a number of different research disciplines. For example, from a strategic management perspective, this research constitutes a starting point for how an important part of the replication strategy, i.e. the store opening process, is conducted among retailers. From a logistics point of view, it contributes to an improved understanding for how the logistics function can contribute to a company-wide function such as a store opening process. The results indicate that important tasks for the logistics function during the opening process are cost calculations, and to plan and execute the physical flow of goods from supplier via CW and further on the stores. In particular, campaigns and the first critical starting kit, require attention and involvement from the logistics function. In a similar manner, 
marketing researchers are served with a better understanding of how organic growth through the opening of new stores could be practiced. The entire process is tightly knitted to the marketing function in the company and the research illuminates many important areas where the marketing function needs to be involved along the process. Examples here are the campaigns, but also issues related to product range and profit calculations.

For practitioners this research increases the understanding for the store opening process in general, but in particular how different coordination mechanisms are used to improve process performance. Since the opening process has not previously been researched, it provides practitioners with an important first overview of a general store opening process based on the practices of eight retail firms.

This explorative research has many limitations, among others due to its relatively

and the research opens up for many new research studies. Three research areas seem especially interesting arenas for further research efforts. First, a life cycle perspective on stores, as indicated by Rosenblum (2005), would be a valuable continuation to this research. By adding the settlement of the stores, a more holistic understanding for having stores as a sales channel would be gained. Second, further research on coordination mechanisms is needed. As shown in this research, retailers apply a mixture of all six coordination mechanisms presented by Mintzberg. The present research does not, however, relate the use of certain mechanisms to process performance, i.e. the research at hand does not investigate if a coordination mechanism is more appropriate than the other. Related to this, differences among the case companies in terms of contingency variables such as size, growth rate, and sector should be investigated in more depth. As a third future research area, a knowledge management perspective on the store opening process would be very valuable. The findings in this research conclude that little or no attention is given to the actual evaluation and improvement of the process itself when the store is opened. As a result of this, a key question becomes how retailers should be able to learn from their previous experiences.

\section{References}

Alexander, A., Cryer, D. and Wood, S. (2008). "Location planning in charity retailing", International Journal of Retail \& Distribution Management, Vol. 36 No. 7, pp. 536-550.

Arnold, S. and Luthra, M. (2000), "Market entry effects of large format retailers: a stakeholder analysis", International Journal of Retail \& Distribution Management, Vol. 28 No. 4, pp. 139-154.

Bengtsson, M. (2008), "The art of replicating", Doctoral Dissertation, Linköping Studies in Arts and Science No. 462, Department of Management and Engineering, Linköping University. 
Chen, H, Daugherty, P., and Roath, A. (2009), "Defining and operationalizing supply chain process integration", Journal of Business Logistics, Vol. 30 No. 1, pp. 63-84.

Craig, C., Ghosh, A. and McLafferty, S. (1984), "Models in the retail location process: A review", Journal of Retailing, Vol. 60 No. 1, pp. 5-36.

Crowston, K. (1997), "A coordination theory approach to organisational process design", Organization Science, Vol. 8 No. 2, pp. 157-175.

Etgar, M. and Rachman-Moore, D. (2008), "International expansion and retail sales: an empirical study", International Journal of Retail \& Distribution Management, Vol. 36 No. 4, pp. 241-259.

Fugate, B., Sahin, F. and Mentzer, J. T. (2006), "Supply chain management coordination mechanisms", Journal of Business Logistics, Vol. 27 No. 2, pp. 129-161.

Gibbert, M., Ruigrok, W., and Wicki, B. (2008), "What passes as a rigorous case study?", Strategic Management Journal, Vol. 29 No. 13, pp. 1465-1474.

Glouberman, S. and Mintzberg, H. (2001), "Managing the care of health and the cure of disease: Part two: Integration”, Health Care Management Review, Winter, pp. 70-84.

Malone, T. and Crowston, K. (1994), “The Interdisciplinary Study of Coordination”, ACM Computing Surveys, Vol. 26 No. 1, pp. 87-119.

Meredith, J. (1989), "Building operations management theory through case and field research", Journal of Operations Management, Vol. 16, pp. 441-454.

Padar, K., Pataki, B. and Sebestyen, Z. (2011), “A comparative analysis of stakeholder and role theories in project management and change management", International journal of management cases, Vol. 13 No 4, pp. 252-260.

Park, Y. and Sternquist, B. (2008), "The global retailer's strategic proposition and choice of entry mode", International Journal of Retail \& Distribution Management, Vol. 36 No. 4, pp. 281-299.

Pietersen, F. (2004), "Handel in Deuschland - Status quo, Strategien, Perpectiven", pp. 31-69. In Riekhoef, H.-C. (2004) "Retail Business in Deutschland: Perspektiven, Strategien, Erfolgsmuster" $1^{\text {st }}$ Edition, Wiesbaden.

Pioch, E., Gerhard, U., Fernie, J. and Arnold, S. (2009), Consumer acceptance and market success: Wal-Mart in the UK and Germany, International Journal of Retail \& Distribution Management, Vol. 37 No. 3, pp. 205-225.

Project Management Institute (2008), A Guide to the Project Management Body of Knowledge (PMBoK® Guide). 4th Edition 
Reynolds, J. and Wood, S. (2010), "Location decision making in retail firms: evolution and challenge", International Journal of Retail \& Distribution Management, Vol. 38 No. $11 / 12$, pp. 828-845.

Rosenblum, P. (2005), Store Lifecycle Management: Creating a unified process for store openings, remodelling, and closings, Business Value Research Series, Aberdeen Group

Sandberg, E., and Bildsten, L. (2011), "Coordination and Waste in the Industrialised Housing Concept", Construction Innovation: Information, Process, Management, Vol. 11 No 1, pp 77-91.

Shanmugam, R. (2013), "Anchor-store quality in malls: an economic analysis", International Journal of Retail \& Distribution Management, Vol. 41 No. 2, pp. 90-112.

Shen, F-Y, and Chang, A. (2011), "Exploring Coordination Goals of Construction Projects", Journal of Management in Engineering, Vol. 27 No 2, pp. 90-96.

Stuart, I., McCutcheon, D., Handfield, R., McLachlin, R. and Samson, D. (2002), "Effective case research in operations management: a process perspective", Journal of Operations Management, Vol. 20, pp. 419-433.

Thomas, S, Tucker, R. and Kelly, W. (1998), “Critical communications variables”, Journal of Construction Engineering and Management, Vol. 124 No 1, pp. 58-66.

Uppal, K. (2008), "Project Management, Cost Engineering, Project Definition, Action Plans or What?" 2008 AACE INTERNATIONAL TRANSACTIONS, pp. 1-11.

Van De Ven, A., Delbecq, A. and Koenig, R. (1976), "Determinants of Coordination Modes within Organizations”, American Sociological Review, Vol. 41 No. 2, pp. 322-338.

Ward, S. (1999), "Assessing and managing important risks". International Journal of Project Management, Vol. 17 No. 6, pp. 331-336.

Ward, S, and Chapman, C. (2008), "Stakeholders and uncertainty management in projects", Construction Management and Economics, Vol. 26, pp. 563-577.

Winter, S., and Szulanski, G. (2001), "Replication as strategy", Organization science, Vol. 12 No.6, pp. 730-743.

Yin, R. K. (2003), Case Study Research: Design and Methods, 2nd Edition, Sage Publications. 


\section{Appendix 1 and 2}

Appendix 1: Some data about the case companies

\begin{tabular}{|c|c|c|c|c|c|c|c|c|}
\hline Short data & Company A & Company B & Company C & Company D & Company $\mathrm{E}$ & Company F & Company G & Company $\mathrm{H}$ \\
\hline Retail sector & Sportswear & Home/house/hobby & Home/house/hobby & Textile & Automotive & Food & Fashion & Furniture \\
\hline $\begin{array}{l}\text { Business } \\
\text { scope }\end{array}$ & $\begin{array}{l}\text { Offers all kinds of } \\
\text { sportswear and } \\
\text { equipment to high } \\
\text { value. Operates } \\
\text { two store concepts. }\end{array}$ & $\begin{array}{l}\text { Low cost retailer, } \\
\text { offering products in } \\
\text { a variety of sectors } \\
\text { such as home, } \\
\text { food, textile, } \\
\text { hobby, pets. } \\
\text { detergents and } \\
\text { tools. }\end{array}$ & $\begin{array}{l}\text { Low cost retailer, } \\
\text { offerint products in } \\
\text { a variety of sectors } \\
\text { such as home, } \\
\text { textiles, and } \\
\text { detergents. }\end{array}$ & $\begin{array}{l}\text { Value-for-money. } \\
\text { but not low price. } \\
\text { of well-known } \\
\text { textile brands. A } \\
\text { minor part of the } \\
\text { stores are } \\
\text { franchisers. }\end{array}$ & $\begin{array}{l}\text { Car spare parts for } \\
\text { sale and adjacent, } \\
\text { affiliated } \\
\text { workshops for } \\
\text { reparations offering } \\
\text { value for money. } \\
\text { Some stores } \\
\text { operated on } \\
\text { franchise-basis. } \\
\text { Some private } \\
\text { labels. }\end{array}$ & $\begin{array}{l}\text { Multinational } \\
\text { company with low- } \\
\text { price food with a } \\
\text { high rate of private } \\
\text { labels. }\end{array}$ & $\begin{array}{l}\text { Fashion retailer } \\
\text { with a mix of own } \\
\text { and premium } \\
\text { brands. Stores } \\
\text { situated at } \\
\text { premium locations } \\
\text { in city centres or } \\
\text { shopping malls. }\end{array}$ & $\begin{array}{l}\text { Offers a mix of } \\
\text { premium brands } \\
\text { and own brands in } \\
\text { a variety of price } \\
\text { segments. About } \\
50 \% \text { of the stores } \\
\text { are franchisers. }\end{array}$ \\
\hline $\begin{array}{l}\text { Turnover } \\
\text { (Euro million) }\end{array}$ & $\begin{array}{l}\text { N/A for Sweden, } \\
490 \text { in total }\end{array}$ & 427 & 80 & 100 (in Sweden) & $\begin{array}{l}196 \text { in Sweden, } 470 \\
\text { in total }\end{array}$ & $N / A$ & 160 & 25 \\
\hline $\begin{array}{l}\text { No of } \\
\text { employees }\end{array}$ & $\begin{array}{l}3000 \text { including part } \\
\text { time, equivalent } \\
\text { with } 1730 \text { full time }\end{array}$ & $\begin{array}{l}1650 \text { including part } \\
\text { time }\end{array}$ & $\begin{array}{l}250 \text { induding part } \\
\text { time }\end{array}$ & $\begin{array}{l}500 \text { in Sweden } \\
\text { (630 in total) }\end{array}$ & $\begin{array}{l}1000 \text { in Sweden } \\
\text { (2000 in total) }\end{array}$ & 2300 in Sweden & 657 & 100 \\
\hline No of stores & 135 in Sweden & 97 & 28 & $\begin{array}{l}132 \text { in Sweden } \\
\text { (158 in total) }\end{array}$ & 144 & 158 (in Sweden) & $\begin{array}{l}110 \text { in Sweden } \\
(113 \text { in total) }\end{array}$ & 30 \\
\hline Growth rate & $\begin{array}{l}\text { Average } 10-12 \text { new } \\
\text { stores annually }\end{array}$ & $\begin{array}{l}\text { Average } 5 \text { new } \\
\text { stores annually }\end{array}$ & $\begin{array}{l}4-5 \text { new stores } \\
\text { annually }\end{array}$ & N/A & $\begin{array}{l}\text { 8-10 new stores } \\
\text { and affiliated } \\
\text { workshop annually }\end{array}$ & $\begin{array}{l}5 \text { new stores } \\
\text { annually }\end{array}$ & $\begin{array}{l}\text { 3-5 new stores } \\
\text { annually }\end{array}$ & $2-3$ stores annually \\
\hline $\begin{array}{l}\text { Geographical } \\
\text { presence }\end{array}$ & $\begin{array}{l}\text { Sweden, Denmark, } \\
\text { Finland }\end{array}$ & Sweden & Sweden & $\begin{array}{l}\text { Sweden, Finland } \\
\text { and Estoniz. }\end{array}$ & $\begin{array}{l}\text { Nordic countries, } \\
\text { mainly Sweden, } \\
\text { Norway, and } \\
\text { Denmark. }\end{array}$ & $\begin{array}{l}25 \text { European } \\
\text { countries }\end{array}$ & $\begin{array}{l}\text { Sweden and } \\
\text { Norway }\end{array}$ & Sweden \\
\hline $\begin{array}{l}\text { Ownership } \\
\text { structure }\end{array}$ & $\begin{array}{l}\text { Family owned, } 25 \% \\
\text { owned by another, } \\
\text { large retail } \\
\text { company }\end{array}$ & Family owned & Family owned & $\begin{array}{l}\text { Listed on the stock } \\
\text { exchange market, } \\
\text { with one large } \\
\text { owner (68\%). }\end{array}$ & $\begin{array}{l}\text { Listed on the stock } \\
\text { exchange market } \\
\text { with one large } \\
\text { owner (29\%). }\end{array}$ & Family owned & $\begin{array}{l}\text { Listed on the stock } \\
\text { exchange market }\end{array}$ & Family owned \\
\hline
\end{tabular}


Appendix 2: The establishment function in the case companies

\begin{tabular}{|c|c|}
\hline Company & The establishment function \\
\hline A & $\begin{array}{l}\text { Responsible for the opening and renovation of stores, but also maintenance of existing ones (e.g. agreements on electricity } \\
\text { and service of escalators). } \\
\text { In total } 7 \text { people including an establishment director, who reports to executive vice president. Executive vice president is } \\
\text { member of the company's establishment council (establishment manager is not). } \\
\text { Other employees: } 3 \text { regional project leaders, } 2 \text { visual merchandisers (responsible for layout and design of the store), and } 1 \\
\text { controller (operational payments, agreements etc). }\end{array}$ \\
\hline B & $\begin{array}{l}\text { The company always outsources renovation and maintenance to the landlord. } \\
\text { Responsibility for a store opening process is divided between an establishment manager with only one employee (who } \\
\text { coordinates maintenance issues) and a project manager responsible for a group of } 10-12 \text { people that are among others } \\
\text { working with store establishments (include project leaders, store layout planners, etc). The establishment manager, mainly } \\
\text { working with location issues, reports directly to the CEO and participates throughout the process to coordinate functions. } \\
\text { The project manager, who is in charge of involved employees, is responsible for purchasing contracts of equipment, shelves, } \\
\text { etc. He reports to the company's sales manager. }\end{array}$ \\
\hline c & $\begin{array}{l}\text { New organisation autumn } 2012 \text { that consists of one manager (also responsible for the headquarters, IT and logistics issues), } \\
\text { and } 2 \text { operations managers. The CEO is also closely related to the group: as an owner of the company he takes all decisions } \\
\text { concerning store openings and is often the first one to visit a potential new store location. In addition to this group, there are } \\
\text { two temporary teams labelled "building teams", consisting of } 5-6 \text { employees from existing stores. These teams, which are } \\
\text { managed by the two operations managers, function as an assembly and stacking resource in the new store during the weeks } \\
\text { before opening (together with the store manager and new personnel in the store). } \\
\text { In addition to the resources described, there is a network of service companies used for the delivery of IT equipment, alarm, } \\
\text { shelves and other similar equipment. }\end{array}$ \\
\hline D & $\begin{array}{l}\text { The establishment function reports to the CFO and consists of four people: Establishment manager (negotiation of rental } \\
\text { agreements, new store locations), Architect and project leader, Administrator (payments, rental agreements, dates for } \\
\text { terminations, etc), and Service and maintenance (coordinates services). The establishment manager participates throughout } \\
\text { the process in different meetings such as the company's establishment council. For building of new stores as well as } \\
\text { renovation projects, a turnkey contract is established. This reduces the scope of the in-house establishment function. }\end{array}$ \\
\hline
\end{tabular}

\section{\begin{tabular}{l|l} 
Company & The establishment function
\end{tabular}}

E

The establishment manager reports to the CEO. The function consists of five people: the establishment manager, two project leaders, and two merchandisers. The manager's main task is locations and relocations, but also to coordinate and inform other functions in the company about future store openings. Project leaders usually work together - one has the operational responsibility for the opening process whereas the other works with the workshop built beside the store. The merchandisers are normally involved when the store is available for the company. The merchandisers order goods, installs and are responsible for the stacking (together with the new personnel).

The Head of Central Services is responsible for the establishment, and is also in charge for construction (the company primarily owns their stores), maintenance, purchasing of equipment (to the stores), and parts of the logistics function. In total 5 people in different geographical regions work as project leaders in charge of new establishments. They work closely with other functions in the company such as regional sales managers, purchasing of equipment, and logistics. For the construction and installation the company trusts a team of external companies.

G A relatively small function (4 people) that reports to the company's CFO. The function consists of an establishment manager, mainly in charge of new store locations and member of the company's establishment council, a project leader who controls and manages a specific store opening process in the later stages, and a controller. The establishment function also includes 2 people working with security, one of whom also works part time with establishment issues. The establishment function is also responsible for maintenance, renegotiation of existing rental agreements, etc.

The visual marketing department is responsible for the company's store concept and development, and is organisationally close to the establishment function, although it is a part of the marketing function. This department is part of the marketing function. At the visual marketing department a store architect is placed, who works together with the establishment function during the opening process.

The company is small, therefore there is no formal establishment function; this role is managed instead by the owner of the company, who manages this alongside his daily (operational) role, which includes product range, sourcing and new store establishments. During the later stages of the opening process there is also an employee from headquarters who personally supervises the process.

All employees at the headquarters get involved in a store opening process; each have individual tasks and responsibilities in the company's checklist for a store opening process. 